Justyna MOKRAS-GRABOWSKA

Uniwersytet Łódzki

\title{
RÓŻNORODNOŚĆ METOD TEORETYCZNYCH I FORM PODEJŚĆ W TURYSTYCE AKTYWNEJ
}

\section{Wprowadzenie}

Aktywne formy turystyki stanowią przedmiot wielu badań zarówno w Polsce, jak i za granicą. Ze względu na pojawiające się w turystyce nowe trendy zauważalna jest znaczna atomizacja form aktywności turystyki aktywnej, przenikająca stopniowo również na grunt polski. Tak zwane tradycyjne formy aktywności, wyróżniane do tej pory głównie jako rodzaje turystyki kwalifikowanej, zyskują coraz bardziej wyszukaną postać. Co więcej, nie zawsze są uprawiane ze znawstwem, pasją i świadomością właściwą turystyce kwalifikowanej sensu stricto. Wiele form aktywności turystycznych, które można z pewnością zaliczyć do szeroko pojmowanej turystyki aktywnej, stanowi często jedynie rodzaj jednorazowej atrakcji, mającej na celu tzw. podniesienie adrenaliny. Jest to podyktowane m.in. działalnością mediów kreujących modę na ekstremalne przeżycia, a także modą na aktywny tryb życia i związaną z tym popularność ofert turystyki aktywnej (ADAMCZYK 2001, s. 253, NIEZGODA 2013, s. 90). Czym jest zatem turystyka aktywna, jakie są jej podstawowe rodzaje, które formy aktywności można określić mianem turystyki aktywnej, a jakie stanowią jedynie formę plenerowej aktywności sportowej? Czym jest w końcu najbardziej wyspecjalizowana forma turystyki aktywnej, czyli turystyka kwalifikowana i czy ma swój odpowiednik poza granicami Polski? 
Opracowanie jest próbą holistycznego podejścia do turystyki aktywnej ma na celu omówienie najważniejszych jej rodzajów, cech uczestników, a także wyróżnienie turystyki kwalifikowanej jako najdoskonalszej jej formy. Wskazano ponadto na różnice w podejściu badawczym do turystyki aktywnej w Polsce i za granicą.

\section{Aktywne formy turystyki - różnorodność podejść}

W literaturze przedmiotu dotyczącej ruchu turystycznego związanego z aktywnością ruchową i sportem występuje wiele określeń i typologii, prowadzących w ostateczności do znacznego chaosu terminologicznego.

Turystyka aktywna (ang. active tourism) to pojęcie najszersze i nadrzędne oznaczające wyjazdy, podczas których podejmowana jest aktywność rekreacyjna (Andrejuk 1998, cyt. za: BOŃCZAK 2013a, s. 52). W literaturze anglojęzycznej obok terminu „active tourism” pojawia się także określenie podobnie brzmiące - ",action tourism", które oznacza uczestnictwo w sportach ekstremalnych (BUjDOSO, DAVID 2013, s. 40).

W wielu definicjach turystyki aktywnej nie podkreśla się jednak konieczności posiadania określonej kondycji psychofizycznej czy też umiejętności posługiwania się sprzętem turystycznym (DURYDIWKA 2010, s. 251). Jest ona zatem formą łagodniejszą od turystyki kwalifikowanej i jest adresowana do szerszego grona odbiorców (NOWACKI 2011, s. 283). Istotne w przypadku turystyki aktywnej są z kolei walory poznawcze oraz wędrówka, czyli pokonywanie przestrzeni (Mazurski, cyt. za: BOŃCZAK 2013b, s. 125).

Najbardziej popularnym modelem zależności pomiędzy turystyką wypoczynkową, aktywną i kwalifikowaną jest zaproponowany przez M. DURYDIWKE (2010, s. 252). Autorka wyróżnia w ramach turystyki aktywnej turystykę kwalifikowaną, a tę dzieli z kolei na: turystykę przygodową i ekstremalną (turystykę ryzyka). Ponadto z modelu wynika, że związki z turystyką aktywną ma także turystyka wypoczynkowa, gdzie podczas tzw. wypoczynku aktywnego turyści podejmują się różnych form aktywności rekreacyjnej. Podział ten wydaje się być bardzo podstawowym i nie wyjaśnia istotnych w tym przypadku zależności pomiędzy turystyką, sportem i rekreacją.

Kompleksowy model takich zależności prezentuje $\mathrm{w}$ swoim artykule B. BOŃCZAK (2013a, s. 56). Wynika z niego, że turystyka aktywna, będąca częścią rekreacji ruchowej, posiada dwie podstawowe odmiany: plenerową 
turystykę aktywną (podejmowanie aktywności $\mathrm{w}$ połączeniu $\mathrm{z}$ walorami środowiska przyrodniczego) oraz turystykę aktywną w obiektach (uprawianą m.in. podczas wyjazdów do SPA). Rodzajami plenerowej turystyki aktywnej są: turystyka kwalifikowana, przygodowa i ekstremalna. Dwa z nich turystyka ekstremalna i kwalifikowana (przenikające się wzajemnie) wykazują ponadto związki z plenerową turystyką sportową, jako jednym z rodzajów turystyki sportowej sensu stricto (omówiona w dalszej części pracy).

Model sugeruje także odrębne potraktowanie turystyki wypoczynkowej, podczas której mogą być wykorzystywane różne formy aktywności fizycznej (np. fitness, pływanie, jazda na rowerze). Autor określa je mianem „sportu dla wszystkich" (zarówno w obiektach, jak i w plenerze). A zatem, według autora, turystyka aktywna jest odrębnym zjawiskiem, gdzie podstawowym motywem jest aktywność ruchowa w plenerze lub w obiektach.

Poniżej autorka omawia wszystkie aktywne rodzaje turystyki, podkreślając różnice w podejściu do nich zarówno autorów polskich, jak i zagranicznych.

Turystyka przygodowa (ang. adventure tourism) to rodzaj turystyki aktywnej, której głównym celem jest przeżycie określonej przygody, podróż „w nieznane”, eksploracja. Jej wyróżnikiem jest aspekt emocjonalny (m.in. związany $\mathrm{z}$ podwyższonym poziomem ryzyka) oraz doznania duchowe i estetyczne mające związek $z$ kontaktem $z$ odmiennym (egzotycznym) środowiskiem przyrodniczym i kulturowym (KUREK, MIKA, PITRUS 2007, s. 257). Zjawisko pojawienia się takiej formy turystyki aktywnej ma niewątpliwie związek ze wzrastającymi potrzebami doznań emocjonalnych (w tym poziomem ryzyka) w społeczeństwach państw silnie zurbanizowanych. Istotne w turystyce przygodowej jest odkrywanie, poszukiwanie, dociekanie.

Do końca lat 90. XX w. turystyka przygodowa była definiowana głównie w zakresie rzeczywistego i domniemanego ryzyka, pomijany był jej aspekt poznawczy, czyli istota samej podróży. A.H. Walle (1997, cyt. za: WEBER 2001, s. 360-361) jako pierwszy zakwestionował takie podejście, a K. WEBER (2001, s. 366) zaproponowała zastosowanie terminu overland adventure tourism (ang.), oznaczającego podróże o charakterze przygodowym, które cechuje: wnikliwość, pogłębianie wiedzy i umiejętności.

Jej cechami są zatem: wyzwanie związane z własnymi umiejętnościami, stymulacja zmysłów i emocji, podekscytowanie, eskapizm (forma psychologicznej ucieczki od codzienności), zaabsorbowanie i kontrastujące emocje. Wspomniane nowe podejście do turystyki przygodowej wskazuje więc na konieczność dość dużego zaangażowania intelektualnego jej uczestnika, 
jednak obecnie coraz częściej turystyka przygodowa jest organizowana przez profesjonalnych touroperatorów, co ma związek $\mathrm{z}$ faktem, że nie wymaga dużego przygotowania psychofizycznego. Wówczas zyskuje tzw. formę komercyjną (fabularyzowana, ang. commercial, package tours). R. Buckley (cyt. za: NOWACKI 2011, s. 283) podaje, że taką turystykę przygodową można rozumieć jako komercyjne zorganizowane wyprawy z przewodnikiem, podczas których główną atrakcję stanowi aktywność w otwartej przestrzeni dostarczająca silnych emocji uczestnikom wyprawy. Jak wnioskuje M. NOWACKI (2011, s. 284) turystyka przygodowa jest zatem często nabywanym za pieniądze krótkotrwałym doświadczeniem wakacyjnym. Takie podejście odróżnia turystykę przygodową od kwalifikowanej sensu stricto, która wymaga znacznie większego przygotowania uczestnika.

Do najpopularniejszych form turystyki przygodowej w Polsce zalicza się: tramping, trekking turystyczny oraz survival (KUREK, MIKA, PITRUS 2007, s. 257). Tramping określany jest mianem "tanie podróżowanie” i odbywa się najczęściej w małych, nieformalnych grupach. W literaturze anglojęzycznej tramping określany jest także terminem backpacking, którego uczestnik (ang. backpacker - obieżyświat) podróżuje z reguły indywidualnie, w odległe, egzotyczne rejony świata oraz korzysta $z$ lokalnej infrastruktury i usług (KUREK, MIKA, PITRUS 2007, s. 276). Trekking turystyczny to z kolei ambitne wyprawy w odległe (często słabo zaludnione) obszary świata. Podkreślana jest tu konieczność znacznego przygotowania psychofizycznego uczestnika. Tego typu wyjazdy coraz częściej stanowią komercyjną ofertę biur podróży, gdzie wędrowanie odbywa się pod opieką wyspecjalizowanych przewodników lub alpinistów. Przygotowanie jest wówczas jedynie podstawowe i odbywa się tuż przed wyjazdem. Survival to forma turystyki przygodowej oznaczająca szkołę przetrwania $\mathrm{w}$ trudnych warunkach środowiska przyrodniczego, przez co znaczny jest aspekt wychowawczy bądź psychologiczny.

Turystyka ekstremalna (turystyka ryzyka) zaliczana jest do turystyki przygodowej (DURYDIWKA 2010, s. 252) i oznacza uprawianie ekstremalnych form rekreacji (sportów ekstremalnych) nastawione na silne doznania emocjonalne. Często towarzyszy jej wyczerpanie fizyczne, a także wysokie ryzyko utraty zdrowia, a nawet życia. Ryzyko jest w przypadku tego rodzaju turystyki najważniejszym elementem. Istotną kwestią $\mathrm{w}$ strukturze motywacyjnej turystyki ekstremalnej są ponadto: chęć wyróżnienia się, realizowania własnych ambicji, indywidualizm, chęć podniesienia statusu społecznego czy prestiż. Uczestnicy turystyki ekstremalnej doświadczają często granic odporności psychicznej i fizycznej. 
Warto także podkreślić, że to właśnie formy turystyki ekstremalnej najczęściej stanowią jedynie rodzaj plenerowej rekreacji przygodowej (zwanej dawniej ryzykowną rekreacją), po które sięga się jednorazowo, często bez konieczności wyjazdu poza stałe miejsce zamieszkania lub bez konieczności pokonywania przestrzeni turystycznej i uprawiania krajoznawstwa.

Odmienne podejście do turystyki ekstremalnej prezentuje J. ADAMCZYK (2011), która proponuje oddzielenie „popkulturowej” jej wersji od zrównoważonej, która jest jej zdaniem uprawiana przez zaawansowanych turystów kwalifikowanych. Zdaniem autorki, dyscypliny turystyki kwalifikowanej rozwijają się obecnie $\mathrm{w}$ coraz bardziej ekstremalne formy (np. turystyka narciarska w skitouring, kajakowa w rafting). Ponadto J. Adamczyk sugeruje oddzielenie od siebie formy aktywności o charakterze sportowym (bez konieczności uprawiania turystyki, przemieszczania się, elementów poznawczych) od turystycznych, gdzie podstawą jest aktywność o charakterze poznawczym.

Zgodnie z zaproponowanym przez B. BoŃCZAKA (2013a, s. 56) modelem relacji pomiędzy sportem, turystyką i rekreacją należy tu zatem wyróżnić tzw. uczestników form aktywności ekstremalnych (sportów ekstremalnych), którzy uprawiają jedynie plenerową aktywność sportową. Wyróżnia ich m.in.: potrzeba silnych przeżyć, chęć odreagowania stresu dnia codziennego, rywalizacja, podążanie za nowościami i chęć podniesienia statusu społecznego poprzez wyróżnienie się z tłumu (ADAMCZYK 2011, s. 257). W przeciwieństwie do zaawansowanych turystów ekstremalnych prezentują oni brak obycia i zaangażowania turystycznego oraz "zaliczanie” odwiedzanych miejsc. Taka postawa odróżnia turystykę ekstremalną - której źródła tkwią w turystyce kwalifikowanej - od innych form aktywności o charakterze sportu (plenerowa aktywność sportowa).

Kolejnym rodzajem aktywnych form turystyki jest turystyka sportowa (usportowiona). Pojęcie to nastręcza najwięcej problemów, głównie ze względu na fakt, że w literaturze przedmiotu pojawiają się definicje wskazujące zarówno na aktywne, jak i bierne uczestnictwo w dyscyplinach sportowych. Turystyka sportowa jest szczególnie popularna w literaturze anglojęzycznej, gdzie oznacza wyjazdy turystyczne związane ze zmianą codziennego trybu życia, w celu uczestnictwa w aktywności sportowej (aktywna turystyka sportowa), jak również w celu oglądania widowisk (wydarzeń) sportowych (turystyka sportowa „eventowa” / fanoturystyka) lub w celu odwiedzania atrakcji sportowych (turystyka sportowa nostalgiczna/sentymentalna) (GIBSON 1998, s. 45). Dodatkowo niektórzy autorzy wyróżniają tury- 
stykę sportowców (wyjazdy na zawody, turnieje), co jednak wydaje się bardzo kontrowersyjne ze względu na ograniczoną dobrowolność tego typu aktywności i zawodowy cel wyjazdu (BOŃCZAK 2013a, s. 58).

Najistotniejszymi cechami turystyki usportowionej są: sportowy lub rekreacyjny charakter podejmowanej aktywności, wysiłek fizyczny, specjalizacja (BOŃCZAK 2013b, s. 124), silne emocje i wrażenia, a także umiejętności techniczne (sprzęt), przygotowanie kondycyjne i uprawnienia formalne (ukończone kursy, certyfikaty). Odrębność turystyki usportowionej wiąże się z faktem, iż często odbywa się ona w ośrodkach sportowych. Jak podaje J. MERSKI (2002, s. 23) termin "turystyka usportowiona" jest za granicą stosowany dla zjawiska określanego w Polsce turystyką kwalifikowaną. Biorąc jednak pod uwagę jej zarówno aktywne, jak i bierne rozumienie, należy podkreślić, że tylko termin aktywna turystyka sportowa (jako jeden z rodzajów turystyki usportowionej) może odpowiadać pojęciu „turystyka kwalifikowana".

Najbardziej wyspecjalizowaną formą turystyki aktywnej jest turystyka kwalifikowana. Pojęcie to pojawiło się na gruncie polskim i nie występuje $\mathrm{w}$ literaturze anglojęzycznej. Zostało wprowadzone do terminologii naukowej przez środowisko PTTK w latach 50. XX w. (KUREK, MIKA, PITRUS 2007, s. 256). Pojawienie się terminu miało związek z próbą wspólnego określenia nowych dziedzin turystyki, które wymagały specjalnego sprzętu i umiejętności (kwalifikacji). Korzenie tego typu działalności na ziemiach polskich wiążą się jednak z powstaniem Galicyjskiego Towarzystwa Tatrzańskiego (1873 r.) (ŁOBOŻEWICZ 1983, s. 7).

Turystyka kwalifikowana oznacza najwyższą formę specjalizacji turystycznej w wybranej dziedzinie (ŁOBOżEWICZ 1983, s. 7). Warto zauważyć, że w wielu definicjach turystyki kwalifikowanej podkreślany jest fakt „kwalifikowania osiągnięć turystycznych" w celu uzyskania coraz wyższych stopni odznak. Turystyka kwalifikowana uznawana jest bowiem za swego rodzaju wyczyn, stąd jej porównania ze sportem kwalifikowanym.

Spośród wielu cech turystyki kwalifikowanej, najczęściej zwraca się uwagę na przygotowanie psychofizyczne uczestnika, samodzielność, zahartowanie na trudy, wysoką kulturę turystyczną, umiejętność posługiwania się sprzętem turystycznym oraz zachowania się $\mathrm{w}$ terenie $\mathrm{i} \mathrm{w}$ obiektach turystycznych, wędrowny charakter podróży, postawę poznawczą (wiedza o środowisku, w którym się przebywa), kształtowanie cech charakteru, odpowiednie przygotowanie do wyjazdu, znajomość danej aktywności turystycznej, doświadczenie turystyczne oraz posiadanie uprawnień formalnych. 
Istotne jest także posiadanie odpowiednich umiejętności (często potwierdzonych certyfikatem) w wybranej dziedzinie turystycznej oraz związek ze środowiskiem przyrodniczym, eksploracją i poznaniem (krajoznawstwem).

Wielu autorów podkreśla ponadto wychowawczy charakter tego rodzaju turystyki (kształtowanie osobowości). Fundamentalnym elementem turystyki kwalifikowanej jest także pasja jej uczestnika oraz uprawianie danej dziedziny aktywności ze znawstwem, co wynika z zaangażowania zarówno $\mathrm{w}$ samą dyscyplinę wybranej aktywności, jak i z pasji związanej z uprawianiem turystyki samej w sobie.

Turystę kwalifikowanego definiują zatem następujące elementy: specyficzne motywacje wewnętrzne i zewnętrzne związane $z$ kwalifikowaniem umiejętności, wysokie umiejętności, doświadczenie i przygotowanie psychofizyczne, aktywna, odpowiedzialna i poznawcza postawa oraz samodzielny sposób organizacji wyjazdu. Efektem ostatecznym są specyficzne korzyści poznawcze, emocjonalne, zdrowotne, wychowawcze czy kwalifikacyjne (rys. 1).

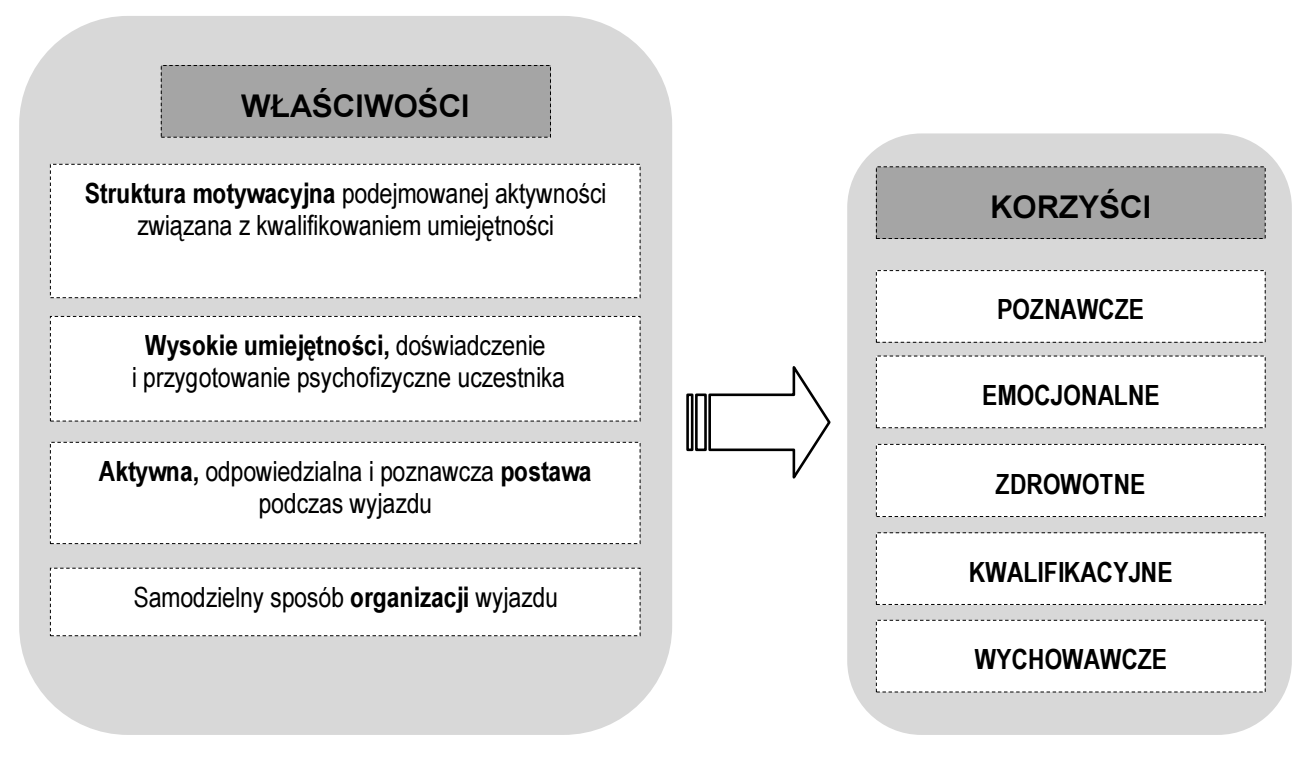

Rys. 1. Turystyka kwalifikowana - właściwości i korzyści Źródło: opracowanie własne na podstawie J. ADAMCZYK (2011),

T. ŁOBOŻEWICZ (1983) 
Motywacje uczestników aktywnych form turystyki odzwierciedlają poziom ich kwalifikacji i zaawansowania turystycznego. W strukturze motywacyjnej turysty kwalifikowanego pojawiają się m.in.: potrzeba kwalifikacji osiągnięć turystycznych, chęć samodzielnego zdobywania wiedzy, wyzwanie, potrzeba walki z własnymi słabościami, głębokie zaangażowanie i samodoskonalenie. Turysta kwalifikowany jest nastawiony na indywidualny rozwój umiejętności w danej dziedzinie turystyki aktywnej i chęć ucieczki od masowej turystyki. Takie cechy oraz wartości są typowe dla zaawansowanej turystyki kwalifikowanej, wymagającej znacznego przygotowania ze strony uczestnika (turystyka świadoma).

W przypadku umiejętności i przygotowania turysty kwalifikowanego znaczenie mają m.in.: doświadczenie $\mathrm{w}$ danej aktywności turystycznej oraz ogólnoturystyczne, wiedza o odwiedzanym regionie, posiadanie odpowiedniego sprzętu, umiejętność jego wykorzystania i serwisowania, a także przygotowanie psychofizyczne i posiadanie uprawnień formalnych (w niektórych przypadkach).

Postawa turysty kwalifikowanego charakteryzuje się aktywnym podejściem do wyjazdu (postawa poznawcza), dużą odpowiedzialnością za siebie i innych uczestników wyprawy oraz wysoką kulturą turystyczną. Ma on dużą wolność i niezależność, wiedzę o odwiedzanym regionie, samodzielnie planuje pobyt, wytrwale podnosi swoje kwalifikacje.

Sposób organizacji wyjazdu oznacza w tym przypadku samodzielne opracowanie tras i realizację wyjazdu. Wielu autorów podkreśla ponadto wędrowny charakter wyjazdów z zakresu turystyki kwalifikowanej, jednak jak twierdzi T. ŁOBOŻEWICZ (1983, s. 9) - nie jest to warunek konieczny.

\section{Formy aktywności plenerowej turystyki aktywnej}

Powszechnym zjawiskiem $\mathrm{w}$ literaturze przedmiotu jest coraz większa atomizacja rodzajów aktywności, jakie mogą być uprawiane w ramach aktywnych form turystyki. Ze względu na duży rozwój rynku turystyki aktywnej w ostatnich latach, a także rozwój sprzętu turystycznego oraz kształtowanie "mody na bycie aktywnym”, liczba form aktywności wyróżnianych w jej obrębie wzrasta. Szczególnie jest to zauważalne w krajach Europy Zachodniej i w USA, gdzie rozwija się popyt na przygodowe i ekstremalne formy turystyki. Ponadto moda wywołana chęcią ucieczki od codzienności wpływa nie tylko na wybór oryginalnej destynacji turystycznej, ale także niecodzien- 
nych rodzajów aktywności (np. skok na bungee, nurkowanie z delfinami) (NIEZGODA 2013, s. 90).

Tabela 1 prezentuje najczęściej pojawiające się w literaturze przedmiotu formy aktywności turystyczno-rekreacyjno-sportowej, które są wykorzystywane w plenerowej turystyce aktywnej. Na podkreślenie zasługuje fakt, że takie rodzaje aktywności, jak: wędrówki piesze nizinne i górskie, kolarstwo nizinne czy kajakarstwo, uprawiane $\mathrm{w}$ postaci łagodniejszej, na niższym poziome specjalizacji, mogą stanowić formy turystyki aktywnej. $Z$ kolei inne, ze względu na wymagane umiejętności posługiwania się specjalistycznym sprzętem i odpowiednie przygotowanie psychofizyczne, należy zaklasyfikować jako formy aktywności turystyki kwalifikowanej (m.in. wspinaczka, speleologia, wiindsurfing, skitouring). Niektóre są najczęściej wykorzystywane w turystyce przygodowej (np. trekking, tramping, survival, baloniarstwo, rajdy przygodowe), inne w ekstremalnej lub sportowej (m.in. skoki spadochronowe, szybownictwo). Różnice bardzo często wiążą się jedynie z podejściem uczestnika do uprawianej aktywności, a także z jego kwalifikacjami, motywacjami, zaangażowaniem i postawą. Na przykład jazda konna może być zarówno aktywnością turystyki aktywnej (gdy jest uprawiana na niższym poziomie zaawansowania, w postaci rekreacyjnej), jak również turystyki kwalifikowanej (gdy wymaga specjalistycznego przygotowania i sprzętu, na wyższym poziomie zaawansowania).

Warto także podkreślić, że niektóre z rodzajów aktywności są jedynie plenerową aktywnością sportową („sport dla wszystkich”), podejmowaną spontanicznie i jednorazowo (np. zorbing, paintball czy dream jumping). Ponadto wiele rodzajów aktywności może również stanowić przedmiot zainteresowania fanoturystyki (podróż w celu uczestnictwa w wydarzeniu sportowym) czy turystyki sportowców.

Pod względem wykorzystania różnych typów środowiska formy aktywności podzielono na trzy podstawowe rodzaje: związane ze środowiskiem lądowym, wodnym i powietrznym. Tabela 1 prezentuje główne, najczęściej spotykane zarówno w literaturze naukowej, jak i w ofertach touroperatorów formy aktywności turystyczno-rekreacyjno-sportowej. Obok nazw polskich autorka podaje także nazwy anglojęzyczne, co wiąże się z faktem częstego ich stosowania w opracowaniach polskich. Ponadto, takie formy jak windsurfing czy skialpinizm nie są na gruncie polskim określane polskimi nazwami. 
Tab. 1. Aktywność turystyczno-rekreacyjno-sportowa

\begin{tabular}{|c|c|c|}
\hline \multicolumn{3}{|c|}{ Aktywność związana ze środowiskiem } \\
\hline lądowym & wodnym & powietrznym \\
\hline [1] & [2] & [3] \\
\hline $\begin{array}{l}\text { Wędrówki piesze nizinne } \\
\text { i górskie (ang. hiking) }\end{array}$ & $\begin{array}{l}\text { Kajakarstwo (ang. kayaking, } \\
\text { canoeing) }\end{array}$ & $\begin{array}{l}\text { Baloniasrtwo } \\
\text { (ang. ballooning) }\end{array}$ \\
\hline $\begin{array}{l}\text { Tramping (backpacking) (ang.) - } \\
\text { wędrówki z plecakiem }\end{array}$ & $\begin{array}{l}\text { Wędrówka kanionami górskimi } \\
\text { (ang. canyoning) }\end{array}$ & $\begin{array}{l}\text { Skoki na bungee } \\
\text { (ang. bungee jumping) }\end{array}$ \\
\hline $\begin{array}{l}\text { Trekking (ang.) - wyprawy } \\
\text { piesze w odludne regiony } \\
\text { świata }\end{array}$ & $\begin{array}{l}\text { Kajakarstwo górskie (ang. white } \\
\text { water rafting) }\end{array}$ & $\begin{array}{l}\text { Skoki spadochronowe } \\
\text { z budynków/obiektów } \\
\text { (ang. base jumping) }\end{array}$ \\
\hline $\begin{array}{l}\text { Kolarstwo nizinne i górskie } \\
\text { (ang. bicycling, mountain biking) }\end{array}$ & $\begin{array}{l}\text { Spływy pontonowe górskimi } \\
\text { rzekami (ang. rafting) }\end{array}$ & $\begin{array}{l}\text { Skoki spadochronowe } \\
\text { z klifów (ang. cliff jumping) }\end{array}$ \\
\hline $\begin{array}{l}\text { Wspinaczka skałkowa i wyso- } \\
\text { kogórska (ang. climbing) }\end{array}$ & $\begin{array}{l}\text { Spływy rwącymi rzekami na } \\
\text { plastikowej desce (ang. hydro- } \\
\text { speeding) }\end{array}$ & $\begin{array}{l}\text { Zjazdy na linie pomiędzy } \\
\text { dwoma obiektami } \\
\text { (ang. dream jumping) }\end{array}$ \\
\hline $\begin{array}{l}\text { Biegi/marsze na orientację } \\
\text { (ang. orienteering) }\end{array}$ & Żeglarstwo (ang. sailing) & Szybownictwo (ang. gliding) \\
\hline $\begin{array}{l}\text { Jazda konna (ang. horseback- } \\
\text { riding) }\end{array}$ & Windsurfing (ang.) & $\begin{array}{l}\text { Paralotniarstwo } \\
\text { (ang. paragliding) }\end{array}$ \\
\hline $\begin{array}{l}\text { Speleologia (ang. caving, } \\
\text { am. spelunking, can. potholing) }\end{array}$ & $\begin{array}{l}\text { Kitesurfing/kiteboarding (ang.) - } \\
\text { odmiana surfingu wykorzy- } \\
\text { stująca latawiec }\end{array}$ & $\begin{array}{l}\text { Spadochroniarstwo } \\
\text { (ang. parachuting, skydiving) }\end{array}$ \\
\hline $\begin{array}{l}\text { Szkoła przetrwania } \\
\text { (ang. survival) }\end{array}$ & $\begin{array}{l}\text { Kiteboarding (ang.) - loty ślizgo- } \\
\text { we i akrobacje w powietrzu } \\
\text { z deską surfingową i spado- } \\
\text { chronem }\end{array}$ & \\
\hline $\begin{array}{l}\text { Wyprawy w psich zaprzęgach } \\
\text { (ang. dog sledding) }\end{array}$ & $\begin{array}{l}\text { Wakeboarding (ang.) - ślizg } \\
\text { na desce surfingowej za } \\
\text { motorówką }\end{array}$ & \\
\hline $\begin{array}{l}\text { Off-road (ang.) - jazda samo- } \\
\text { chodem po drogach nieutwar- } \\
\text { dzonych }\end{array}$ & $\begin{array}{l}\text { Bodyboarding (ang.) - odmiana } \\
\text { surfingu (bez pędnika) }\end{array}$ & \\
\hline $\begin{array}{l}\text { Jazda quadami (ang. quad } \\
\text { biking) }\end{array}$ & $\begin{array}{l}\text { Narciarstwo wodne (ang. water- } \\
\text { skiing) }\end{array}$ & \\
\hline $\begin{array}{l}\text { Jazda na motorze (ang. motor- } \\
\text { cycling) }\end{array}$ & $\begin{array}{l}\text { Nurkowanie (ang. snorkelling, } \\
\text { scuba diving) }\end{array}$ & \\
\hline $\begin{array}{l}\text { Narciarstwo zjazdowe } \\
\text { (ang. downhill skiing) }\end{array}$ & Bojery (ang. iceboats) & \\
\hline $\begin{array}{l}\text { Narciarstwo biegowe } \\
\text { (ang. backcountry skiing) }\end{array}$ & & \\
\hline $\begin{array}{l}\text { Wędrówki górskie na nartach } \\
\text { (ang. skitouring) }\end{array}$ & & \\
\hline $\begin{array}{l}\text { Skialpinizm - zjazdy/ wędrów- } \\
\text { ka/ wspinaczka na nartach }\end{array}$ & & \\
\hline $\begin{array}{l}\text { Snowboard (ang.) - ewolucje na } \\
\text { desce snowboardowej }\end{array}$ & & \\
\hline
\end{tabular}




\begin{tabular}{|l|l|l|}
\hline \multicolumn{1}{|c|}{$[1]$} & [2] & \\
\hline $\begin{array}{l}\text { Mountainboarding (ang.) - } \\
\text { zjazdy ze stoków górskich na } \\
\text { desce wyposażonej w kółka }\end{array}$ & & \\
\cline { 1 - 1 } $\begin{array}{l}\text { Zorbing (ang.) - staczanie się ze } \\
\text { zboczy górskich w plastikowej } \\
\text { kuli }\end{array}$ & & \\
\cline { 1 - 1 } $\begin{array}{l}\text { Paintball (ang.) - plenerowe } \\
\text { gry wojenne z wykorzysta- } \\
\text { niem broni pneumatycznej }\end{array}$ & & \\
\cline { 1 - 1 } $\begin{array}{l}\text { Wyprawy eksploracyjne } \\
\text { (ang. wilderness adventures, } \\
\text { wildlife watching) }\end{array}$ & & \\
\cline { 1 - 1 } Rajdy przygodowe & & \\
(ang. adventure racing, AR) & & \\
\hline
\end{tabular}

Źródło: opracowanie własne na podstawie: G. POMFERT (2006), A.W. EWERT, S.J. HOLLENHORST (1997), R. TOMIK (2013), J. MERSKI, J. WARECKA (2009), T. ŁOBOŻEWICZ (1983).

Warto dodać, że w polskiej literaturze przedmiotu za najpopularniejsze formy uznaje się: turystykę pieszą (nizinną i górską), kolarską, kajakową, narciarską, żeglarską i nurkowanie. W latach 80. minionego stulecia T. ŁOBOŻEWICZ (1983, s. 41) do form turystyki kwalifikowanej zaliczył ponadto: turystykę motorową (samochodową i motocyklową), imprezy na orientację i turystykę kempingową. Z kolei R. TOMIK (2013, s. 16) dodaje do swojej klasyfikacji m.in. trekking, wspinaczkę, speleologię, rafting, windsurfing, narciarstwo zjazdowe i biegowe, snowboarding, skitouring oraz lotniarstwo. Co ciekawe, autor określa je mianem form aktywnej turystyki sportowej.

Pojawiające się $\mathrm{w}$ literaturze przedmiotu klasyfikacje $\mathrm{z}$ reguły są niepełne - formy aktywności traktowane są w sposób wybiórczy, według uznania autorów. W polskich opracowaniach są wymieniane głównie jako formy turystyki kwalifikowanej, podczas gdy w zagranicznych - przygodowej lub ekstremalnej. Istotne wydaje się zatem ich kompleksowe ujęcie, z jednoczesnym podkreśleniem, że mogą być wykorzystywane przez różne rodzaje aktywnych form turystyki, a także stanowić formę plenerowej aktywności sportowej. W tym ostatnim przypadku nie ma znaczenia bowiem element obowiązkowy w turystyce - wyjazd poza stałe miejsce zamieszkania. Moga być uprawiane w czasie wolnym, w postaci rekreacyjnej (m.in. kolarstwo, wędrówki piesze czy jazda konna). 


\section{Podsumowanie}

„Turystyka aktywna" to szerokie pojęcie, w ramach którego wyróżniana jest najdoskonalsza jej forma, wymagająca znawstwa i przygotowania - turystyka kwalifikowana. Uznawana za „matkę polskiej turystyki”, a także za turystykę świadomą, współcześnie oferuje coraz więcej form aktywności wraz z odmianami przygodowymi i ekstremalnymi. Mimo że nie posiada terminologicznego odpowiednika poza granicami Polski, istotne jest popularyzowanie tak zaawansowanego podejścia ze względu na znaczne korzyści poznawcze, wychowawcze czy zdrowotne. Upowszechniana w Polsce głównie przez środowisko PTTK, mająca znaczny wymiar ideologiczny, dziś zmienia swoje oblicze za sprawą nowych możliwości technologicznych. Nie bez znaczenia są także współczesne zachowania konsumentów (turystów) w gospodarce rynkowej, w tym moda kształtująca podaż turystyczną.

Zaprezentowane spojrzenie na całokształt zjawisk związanych z aktywnymi formami turystyki jest próbą ich uporządkowania, lecz z pewnością nie wyczerpuje tematu - może jednak stanowić podstawę teoretyczną do dalszych badań i rozważań.

\section{Bibliografia}

ADAMCZYK J., 2011, Turystyka ekstremalna - popularność i niewykorzystany potencjat, „Studia i Materiały CEPL w Rogowie", 13, 3 (28), s. 253-259.

BOŃCZAK 2013a, Aktywne formy turystyki - problemy terminologiczne, [w:] R. Wiluś, J. Wojciechowska (red.), Nowe-stare formy turystyki w przestrzeni, ser. „Warsztaty z Geografii Turyzmu, 3, Wyd. Uniwersytetu Łódzkiego, s. 49-62.

BOŃCZAK B., 2013b, Turystyka aktywna, kwalifikowana czy sportowa? Wzajemne relacje między zjawiskami w świetle literatury polskiej i zagranicznej, [w:] R. Pawlusiński (red.), Wspótczesne uwarunkowania i problemy rozwoju turystyki, Wyd. Uniwersytetu Jagiellońskiego, Kraków, s. 121-134.

BUJDOSO Z., DAVID L., 2013, Extreme sports and other activities in tourism with special regard to the Matra Mountain, "Journal of Physical Education and Sport", 13 (1), ,'Art" 7, s. 39-45.

DURYDIWKA M., 2010, Definicja i zakres pojęcia "turystyka kwalifikowana (turystyka aktywna)", [w:] A. Kowalczyk (red.), Turystyka zrównoważona, PWN, Warszawa, s. 249-289.

EWERT A.W., HOLLENHORST S.J., 1997, Adventure recreation and its implications for wilderness, "Science and Research", 3, 2, s. 21-26.

GIBSON H.J., 1998, Sport tourism: a critical analysis of research, „Sport Management Review”, 1, s. 45-76.

KUREK W., MiKA M., PITRUS E., 2007, Formy turystyki kwalifikowanej, [w:] W. Kurek (red.) Turystyka, Wyd. Naukowe PWN, s. 256-279.

ŁOBOŻEWICZ T., 1983, Turystyka kwalifikowana, Wyd. PTTK „,Kraj”, Warszawa.

MERSKI J., 2002, Turystyka kwalifikowana, Wyd. WSE, Warszawa.

MERSKI J., WARECKA J., 2009, Turystyka kwalifikowana. Turystyka aktywna, Almamer, WSE, Warszawa. 
NieZgodA A., 2013, Wptyw mody na rozwój turystyki, [w:] R. Pawlusiński (red.), Wspótczesne uwarunkowania i problemy rozwoju turystyki, Wyd. Uniwersytetu Jagiellońskiego, Kraków, s. 85-92.

NOWACKI M., 2011, Czym jest turystyka przygodowa?, [w:] W. Siwiński, D. Mucha-Szajek (red.) Teoria i praktyka ustug turystycznych, rekreacyjnych i hotelarsko-żywieniowych w świetle badan, WSHiG, Poznań, s. 281-290.

POMFRET G., 2006, Mountaineering adventure tourists: a conceptual framework for research, „Tourism Management", 27, s. 113-123.

TOMIK R., 2013, Active sport tourism - a survey of students of tourism and recreation, „Journal of Tourism, Recreation \& Sport Management", 1, s. 13-20.

WEBER K., 2001, Outdoor adventure tourism. A review of research approaches, "Annals of Tourism Research", 28, 2, s. 360-377. 